$$
D . O E / O R / 2 / 400-T 415
$$

\title{
ORNL AND THE UNIVERSITY OF TENNESSEE-- \\ A PARTNERSHIP FOR THE FUTURE
}

\author{
by \\ Dr. Alvin W. Trivelpiece \\ Oak Ridge National Laboratory*
}

DOE/OR/ 21400--T415

DE9 0008864

To be delivered to

The University of Tennessee Development Council

at the Shiloh Room, University Center, University of Tennessee

\section{DISCLAIMER}

This report was prepared as an account of work sponsored by an agency of the United States Government. Neither the United States Government nor any agency thereof, nor any of their employees, makes any warranty, express or implied, or assumes any legal liability or responsibility for the accuracy, completeness, or usefulness of any information, apparatus, product, or process disclosed, or represents that its use would not infringe privately owned rights. Reference herein to any specific commercial product, process, or service by trade name, trademark, manufacturer, or otherwise does not necessarily constitute or imply its endorsement, recommendation, or favoring by the United States Government or any agency thereof. The views and opinions of authors expressed herein do not necessarily state or reflect those of the United States Government or any agency thereof.

September 15, 1989

*Operated by Martin Marietta Energy Systems, Inc., for the U.S. Department of Energy under Contract No. DE-AC05-840R21400.

This document is

PUBLICL" RRLEASABLE

hasy Cgrefiame

Authorizing Official

Date: $03 / 22 / 2006$ 


\section{DISCLAIMER}

This report was prepared as an account of work sponsored by an agency of the United States Government. Neither the United States Government nor any agency Thereof, nor any of their employees, makes any warranty, express or implied, or assumes any legal liability or responsibility for the accuracy, completeness, or usefulness of any information, apparatus, product, or process disclosed, or represents that its use would not infringe privately owned rights. Reference herein to any specific commercial product, process, or service by trade name, trademark, manufacturer, or otherwise does not necessarily constitute or imply its endorsement, recommendation, or favoring by the United States Government or any agency thereof. The views and opinions of authors expressed herein do not necessarily state or reflect those of the United States Government or any agency thereof. 


\section{DISCLAIMER}

Portions of this document may be illegible in electronic image products. Images are produced from the best available original document. 


\section{ORNL AND THE UNIVERSITY OF TENNESSEE--}

A PARTNERSHIP FOR THE FUTURE

To be delivered to

\section{The University of Tennessee Development Council \\ at the Shiloh Room, University Center, \\ University of Tennessee \\ September 15, 1989}

Oak Ridge National Laboratory and the University of TennesseeKnoxville enjoy a particularly beneficial relationship that both enhances and promotes our individual academic and research interests and also aids economic development in East Tennessee.

Before I discuss this partnership, I would like to tell you a little about Oak Ridge National Laboratory. We are the oldest and largest of the five multiprogram energy research laboratories. ORNL is operated by Martin Marietta Energy Systems for the U.S. Department of Energy. Our mission is to conduct applied research and engineering development in support of DOE's programs in fusion, fission, conservation, fossil and other technologies. We also perform basic scientific research in selected areas of physical and life sciences. Our facility has about 4500 staff including 1500 scientists and engineers. Over 800 of these professionals have their $\mathrm{Ph} . \mathrm{D}$. Our annual budget is about $\$ 500$ million with $80 \%$ of our work for the Department of Energy. The other 20\% is for government agencies such as the Nuclear Regulatory Commission, Department of Defense, Environmental Protection Agency, Bureau 
of Engraving and Printing and the Agency for International Development.

ORNL has about 4.1 million square feet of gross building space with a replacement cost estimated at $\$ 2.5$ billion. We are responsible for environmental management of a large portion of the 58 square mile Oak Ridge Reservation. About 30,000 people visit ORNL annually and we host 2300 guests that stay 2 weeks or longer. About a third of these guests are from industry and the rest are mainly from universities.

World War II saw the establishment of Clinton Laboratories (as ORNL was then called) in close proximity to the University of Tennessee. Important contributions were being made in the new field of atomic energy. At the end of the war, the Oak Ridge research community felt the need for a closer educational presence. UT had initiated its first doctoral program (chemistry) in 1944 and agreement was soon reached to establish a branch of the UT Graduate School at Clinton Laboratories. This program began in October 1945 and allowed young scientists to start a graduate program in chemistry or physics without interrupting their employment. Initially taught by senior scientists at Clinton Laboratories, the program soon moved into the city to accommodate students from the other Oak Ridge facilities. Within the next several years, doctoral programs in physics, botany, mathematics, bacteriology, zoology, and chemical engineering were developed. 
In many cases graduate courses were first offered in Oak Ridge and then also moved to Knoxville.

After 1952, the Oak Ridge Resident Graduate Program was expanded to include students who were not employees of the Oak Ridge contractors. This program has been extremely successful with current enrollments of 250 per semester. Recently, the radiation protection concentration in the nuclear engineering program and the mixed waste management concentration in the environmental engineering program were initiated in Oak Ridge before being available in Knoxville.

Two strong UTK-ORNL programs are the UTK graduate schools located at ORNL. The Graduate School of Biomedical Sciences began in 1965 and is housed in ORNL's Biology Division. Currently it has 28 full time and 4 part-time doctoral students. Through last semester, 124 doctorates and 20 masters degrees have been awarded. The Graduate Program in Ecology is affiliated with our Environmental Sciences Division and started in 1969. Since its beginning, 87 doctorates and 148 masters degrees have been granted. These programs also involve postdoctoral research appointments with ORNL.

For many years, there has been cooperative research at a formal level and other, more informal, associations through participation at seminars and advisory activities. Our two institutions work together to review research proposals using human tissue. ORNL 
staff serve as adjunct UTK faculty. Collaboration between ORNL and UTK evolved into the Science Alliance in 1984. The oldest and largest of Tennessee's Centers of Excellence, the Science Alliance, was established with the support of the Tennessee Higher Education Commission. The comerstone of the Alliance is the Distinguished Scientist Program. Its purpose is to attract scientists of significant stature to strengthen R\&D in this region. Eleven internationally recognized scientists now have joint positions at ORNL and UTK. They are in such areas as particle physics theory, nuclear engineering, computational sciences, and polymer chemistry. The scientists hold a tenured full professor position at UTK and an appointment as a senior research scientists at ORNL. Expenses for this program are split evenly between the two institutions. Another staff sharing experience involves approximately ten professors splitting their time 80-20 between ORNL and UTK. Dr. Lee Reidinger, Director of the Science Alliance, and Dr. Bob Hatcher, a participant in the Distinguished Scientist program, will discuss this program in greater detail shortly.

These programs have worked so well that ORNL and UTK are working on a Collaborating Scientist program. We hope to attract scientists and engineers with a rising national stature and reputation at all academic levels. It is expected that this will enhance the quality of science, technology, education, and industrial development in the Knoxville/Oak Ridge area. 
Another important aspect of the Science Alliance is the Summer Research Fellows Program. This activity brings 100 of the nation's most promising undergraduate science students to the university where they work for ten weeks with researchers at the university and the national laboratory. Joint graduate programs are also a part of the Science Alliance. These include a Master of Science program in biotechnology and a graduate program in measurement and control engineering.

All of this means a great deal of interaction between ORNL and the University of Tennessee, Knoxville. This has been growing significantly in the last several years. In fiscal year 1985, ORNL had about $\$ 3$ million in $R \& D$ subcontracts with the University. In FY 1988, this grew to over $\$ 12$ million and this fiscal year, it is expected that over \$ 14 million will be obligated. The University of Tennessee, Knoxville receives over $60 \%$ of the subcontract funds ORNL provides to universities.

Everyone benefits from programs like this. The research community benefits from sharing ideas and resources and the students benefit from this supplement to their classroom activities. I would like to share one example of this that began in 1987 with our Technology Transfer efforts. Graduate students in the M.B.A. program were hired to perform marketing studies. These special marketing projects involved transferring technology developed at ORNL into the industrial sector. The students in this program work full time in the summer as interns and part time during the school 
year. So far, 18 students have been part of the program and all have found this experience to be extremely beneficial. They have been involved in both licensing and partnership development and in identifying potential uses of new technology. The students have been exposed to the challenges of bridging the gap between ORNL and the commercial marketplace. They have become aware of the BIG PICTURE of emerging technologies and the trends involving potential uses in the economy.

Our cooperative approach to funding large projects has allowed both of our institutions to obtain research facilities during times of stiff competition for construction dollars. Our first cooperative effort followed the completion of the Holifield Heavy Ion Research Facility. Dedicated in 1980, this structure is the equivalent of a 15 story building and makes possible extensive exploration of the behavior of nuclear matter. As a user facility, it is open to researchers throughout the scientific community including universities, research centers, and industry. It was soon discovered that besides experimental facilities, visiting scientists need other accommodations. These include a conference room, office space, sleeping alcoves for use during experiments, and individual living areas for longer term visitors. The Joint Institute for Heavy Ion Research was built with funding provided by The University of Tennessee, Vanderbilt University, and ORNL through the Department of Energy. Its innovative design including a partial underground location, allows the 4000 square foot structur. 10 achieve energy savings of $70 \%$. 
A similar cooperative agreement was reached recently on the Gammasphere. This facility would also be for nuclear physics research and would allow the study of gamma rays with greater resolution than present equipment can manage. The University of Tennessee and Vanderbilt University have each pledged \$100,000 in matching funds and the state of Tennessee has pledged $\$ 800,000$. A panel for the Department of Energy has recommended that if the project is to built, it should be built at ORNL. Our strong program to accommodate scientists from outside the Laboratory who wish to use the facilities was cited by the panel as a primary reason for their recommendation. Over the next several months, DOE will decide if it should include this facility in its 1991 budget. If approved, this would make Tennessee the premier world center in nuclear structure research. More than 300 scientists would be expected to visit the Gammasphere annually.

Another venture that has been proposed is resource sharing involving the libraries at UTK and ORNL. Joint agreements have been proposed, and are now in the hands of the lawyers, to allow staff to have free borrowing privileges and access to the other institution's library. The value of these libraries will be enhanced by increasing the availability of the collections. It is also hoped that decisions on future collection development will be made jointly. This will help alleviate the impact of $15 \%$ annual increases in journal prices that the libraries have absorbed over the last decade. 
ORNL is taking the initiative to establish itself as a world class resource capable of responding to the changing needs of our country. Although John Donne said "no man is an island" several hundred years ago, he may as well have been referring to today's interdependence of countries on environmental issues. The establishment of the Center for Global Environmental Studies is designed to focus the Laboratory's resources more strongly on important environmental issues that are larger in scale and operate over longer time periods than traditional environmental concerns. These issues, heightened by current attention to possible global warming as a consequence of the "greenhouse effect." While I was Director of the DOE's Office of Energy Research, I proposed the construction of the Superconducting Super Collider. This new high energy physics project will require the development of new, highly efficient, detector systems. With ORNL's expertise in detector $R \& D, I$ hope that we can play an important role in the advancing this technology.

For the future, I see ORNL striving to increase its role in education. Efforts must continue to increase the technical literacy of the nation's population. ORNL and the other Department of Energy laboratories are a large consumer of talent and will not be able to continue their work without an adequate supply of talented scientists, engineers, and support staff. We need to be contributors to this pool of talent as well as being consumers of the talent. For many years, the national laboratories were isolated, and contact with outside organizations was not regarded highly. This is now changed. 
National laboratories should increase their efforts not only at the university level but also in other precollege activities. I regard working with students and their teachers as an important part of our mission. The worst thing that can possibly happen is that the kids might learn something.

ORNL and the University of Tennessee, Knoxville, have established a partnership that is advantageous to both of us. We have identified opportunities for cooperation and resource sharing that develop our talents and enrich our lives. For Tennessee to continue to grow, strong cooperation is needed among government, universities, and industry. Robert Solow, the 1987 Nobel Prize winner in economics, has studied the economic impact of science.

"What I got interested in was the question of what makes a modern industrial economy grow...we owe it all to the growth of science and technology." 